\title{
Receptive and productive skills of English /// and /r/ by Japanese college students in relation to their motivation
}

Yuichi Todaka

Department of Intercultural Studies, Miyazaki Municipal University, Japan

https://doi.org/10.36505/ExLing-2008/02/0054/000113

\begin{abstract}
The objectives of the present study were threefold: (1) the effects of training in $/ r /-/ 1 /$ perceptual identification on $/ \mathrm{r} / \mathrm{-} / \mathrm{l} /$ production; (2) the effects of training in $/ \mathrm{r} /-\mathrm{l}$ 1/ production on /r/-/1/ perceptual identification; and (3) the effects of perceptual and production training on learners' motivation to study English. Results indicate that both the perceptual and the production training sessions resulted in improving not only the intended skill but both the receptive and productive skills. Thus, both receptive or productive skill sessions can be used to promote Japanese college EFL learners English oral communication skills. Nevertheless, the motivation questionnaire shows (1) the importance for teachers to encourage their students to self-study for improving receptive skill and (2) the significance for teachers to understand the efficacy of output practice in small groups to help their students gain confidence in productive skill.
\end{abstract}

Key words: receptive, productive, motivation

\section{Introduction}

Nonnative speakers have extreme difficulty receiving and producing certain non-native phonetic contrasts (e.g., Flege, 1988; Goto, 1971). For instance, Japanese learners of English have difficulty discriminating /r/ and /1/ sounds. According to Ladefoged (2001), / $/$ / is lateral approximant and $/ \mathrm{r} /$ is central approximant while Japanese one is an apico-alveolar tap which is phonetically more similar to flapped / $\mathrm{t} /$ and /d/ in American English (Price, 1981; Vance, 1987 cited in Aoyama et al., 2004). These three phonetic contrasts are, therefore, completely different from one another from both perceptual and articulatory points of view. Nonetheless, the vast majority of Japanese adult second language learners of English recognize both /r/ and /1/ sounds the same as Japanese apico-alveolar tap.

The relationship between speech perception and speech production has also been a long-standing issue in speech science and experimental phonetics (Bradlow, et al. 1997). For example, a rounded vowel in French $(/ y /)$ is mispronounced as a high-front vowel (/i/) by Portuguese, but it is mispronounced as a high-back vowel (/u/) by English speakers.

Skehan (1989) suggested that learners' language aptitudes vary individually, and such variation has considerable significance for language learning success. However, assuming that aptitude was innate and not

ExLing 2008: Proceedings of 2nd Tutorial and Research Workshop on Experimental Linguistics, 25-27 August 2008, Athens, Greece 
changeable, other factors, such as attitudes towards the target language and the motivation to learn it, can become the key for L2 acquisition (Baba 1997).

In the present study, we, therefore, investigated: (1) the effects of training in $/ \mathrm{r} /-/ 1 /$ perceptual identification on $/ \mathrm{r} /-/ 1 /$ production; (2) the effects of training in $/ \mathrm{r} /-/ 1 /$ production on $/ \mathrm{r} /-/ 1 /$ perceptual identification; and (3) the effects of perceptual and production training on learners' motivation to study English.

\section{Method \\ Subjects study period}

Thirteen female students at Miyazaki municipal university participated in the present study during the spring semester in 2007. Six joined in perceptual training sessions, and the others participated in production training sessions.

\section{Assessment}

Assessment for perceptual identification

The subjects' improvements in perceptual identification ability were assessed by an identification test of a synthetic /rait/-/lait/ continuum which was downloaded from the Advanced Telecommunications Research Institute International's website (ATRII 2008). In the identification test, the subjects were asked to identify the initial consonant in word which was synthesized artificially, and to make a forced choice between $/ \mathrm{r} /, / 1 /$, and $/ \mathrm{w} /$.

\section{Assessment for production}

Auditory judgments by six native English speakers were used to assess the subjects' improvements in their pronunciations of $/ \mathrm{r} /$ and $/ 1 /$ in words.

\section{Results}

\section{Test results}

The subjects showed more than $80 \%$ correct responses for the stimuli on either side at the post-test (less than $60 \%$ and $70 \%$ for $/ \mathrm{r} /$ and $/ 1 /$ at the pretest). Rate of responses to $/ \mathrm{w} /$ for all stimuli also decreased. The following figure indicates an example of the means of results of identification tests by both groups. 
Figure 1. mean results of identification tests and auditory judgments by both groups.

\section{Pre-training results}

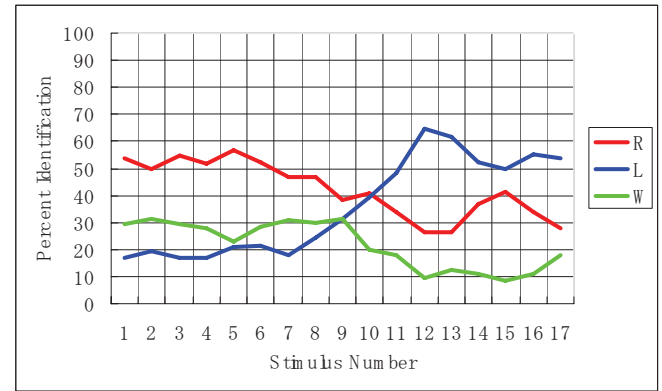

Post-training results

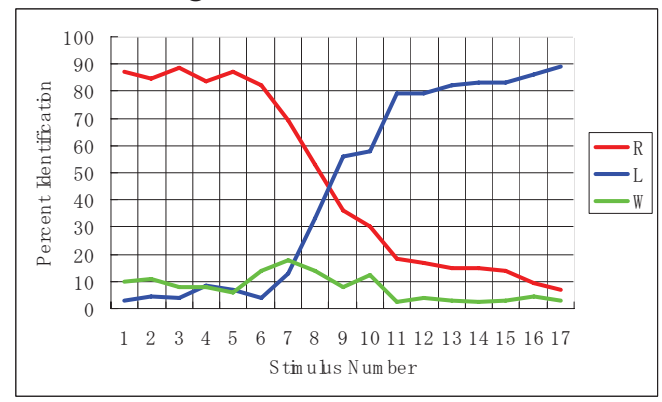

Therefore the subjects in both groups showed improvements in their receptive skills

Based upon the native-speaker assessment, the subjects in both groups showed some improvements regardless of types of training they had received; however, we could say that the perceptual group had performed better if you took the deterioration rate into consideration.

\section{Questionnaire results}

We gave the subjects the same five-point scale questionnaire to the subjects twice to investigate any changes in their motivation to study English. Thirteen questions on the questionnaire were taken from Kiss and Nikolov (2006), and were translated into Japanese.

The results indicate an interesting dichotomy between the perceptual and the production group members. Thus, the importance of cooperative learning in constructing necessary L2 skills (Kaufman 2004, Slavin 2003) and the significance of intrinsic motivation (Wu 2003, Noels et al. 2000) have been reconfirmed in this study. 


\section{Conclusion and limitations}

Both perceptual and production training sessions resulted in helping the subjects improve both their perceptive and productive skills to some extent. Nevertheless, it is much more important to consider the subjects' motivation to further study their receptive and productive skills of the targeted consonants, as our ultimate goals as instructors is to assist learners in becoming autonomous learners, which, in turn, results in long-term retention of learned materials. If so, individualized teaching method should not be overlooked as was found in the present study. Both cooperative learning and customized learning go hand in hand in helping our learners acquire the target sounds.

\section{References}

Advanced Telecommunications Research Institute International. 2008. Internet Koukai Jikken. Retrieved from http://atrcall.isd.atr.co.jp/

Aoyama, K., Flege, J. E., Guion, S. G., Yamada, R. A., and Yamada, T. 2004.

Perceived phonetic dissimilarity and L2 speech learning: the case of Japanese $/ \mathrm{r} /$ and English /1/ and /r/ Journal of Phonetics 32 pp.233-250

Baba, T. (ed.) 1997. Eigo Speaking Ron. Tokyo: Kagensya.

Bradlow, A.R., Pisoni, D.B., Akahane-Yamada, R. and Tohkura, Y. 1997. Training Japanese listeners to identify English /r/ and /1/: IV. Some effects of perceptual learning on speech production. Acoustical Society of America 101, 4, 2299-2310.

Goto, H. 1971. Auditory perception by normal Japanese adults of the sounds "l" and "r". Neuro-psychologia 9, 317-323.

Flege, J.E. 1988. The production and perception of foreign language speech sounds. In Winitz, H. (ed.) Human Communication and Its Disorders: A Review, 233271. Norwood, NJ: Ablex.

Strange, W. (ed.) Language Research. Maryland: York Press.

Kaufman, D. 2004. Constructivist issues in language learning and teaching. Annual Review of Applied Linguistics 24, 303-319.

Kiss, C. and Nikolov, M. 2006. Developing, piloting, and validating an instrument to measure young learner's aptitude. Language Learning 55 1, 99-150.

Noeuls, K., Pelletier, L., Clement, R. and Vallerand, R. 2000. Why are you learning a second language? Motivational orientations and self-determination theory. Language Learning 50, 57-85.

Skehan, P. 1989. Individual Differences in Second Language Learning. London: Edward Arnold.

$\mathrm{Wu}, \mathrm{W} .2003$. Intrinsic motivation and young language learners: The impact of the classroom environment. System, 31, 501-517. 